\title{
Neuromodulation via Focal Radiation: Radiomodulation Update
}

\author{
M. Bret Schneider ${ }^{1,2}$, Brian Walcott ${ }^{3,4}$, John R. Adler Jr. ${ }^{5}$ \\ 1. Chief Medical Officer, Zap Surgical Systems, Inc., San Carlos, USA 2. Department of Psychiatry, Stanford University \\ School of Medicine, Stanford, USA 3. Neurosurgery, University of Chicago, Chicago, USA 4. Neurosurgery, Northshore \\ University HealthSystem, Evanston, USA 5. Department of Neurosurgery, Stanford University School of Medicine, \\ Stanford, USA
}

Corresponding author: M. Bret Schneider, bret@zapsurgical.com

\begin{abstract}
When radiation is focally delivered to brain tissue at sub-ablative doses, neural activity may be altered. When done at a specific brain circuit node or connection, this is referred to as "radiomodulation." Radiationinduced effects on brain tissue, basic science, and clinical research that supports the radiomodulation hypothesis are reviewed in this article. We review progress in defining the necessary parameters in terms of dose, volumes, and anatomical location. It may be possible to deliver therapeutic neuromodulation that is non-invasive, non-destructive, and durable.
\end{abstract}

Categories: Neurology, Psychiatry, Neurosurgery

Keywords: radiation, neuromodulation, radiomodulation, radiosurgery, functional disorders, psychiatric disorders, behavioral disorders

\section{Introduction And Background}

Behavioral diseases and other functional disorders result in incalculable human suffering and tremendous economic losses [1]. Recent advances in basic neuroscience inform us that the function of discrete, pathological brain circuits underlie such functional disorders [2]. With this understanding, various techniques have been developed for altering pathologic circuit function, and in doing so have fostered and validated the concept of clinical neuromodulation. By manipulating the function of these circuits at specific targets in human subjects, former hypotheses have been validated and are now the rationale for clinical neuromodulation.

Review began 04/12/2021 Review ended 04/23/2021 Published 04/26/2021

๑) Copyright 2021

Schneider et al. This is an open access article distributed under the terms of the Creative Commons Attribution License CC-BY 4.0., which permits unrestricted use, distribution, and reproduction in any medium, provided the original author and source are credited.
Radiosurgery has been proposed as a method of producing neuromodulation by Regis et al., who noted radiosurgery effects on epileptic tissue that otherwise seemed to retain basic neurological function $[3,4]$. Schneider et al. proposed that the radiation-induced neuromodulation principle could be applied to targeted locations within known brain circuits for the treatment of some severe and refractory psychiatric and behavioral conditions [5]. When a focal radiation dose is administered to a node or connection within a known brain circuit for a specific intended effect, this is referred to as "radiomodulation." More work is required to establish that this research hypothesis can be effective, safe, and durable. In particular, it will be important to establish correct network targets and the pertinent volumes and doses.

\section{Review}

\section{Neuromodulation}

One aspect of neuromodulation is the alteration of activity levels in the brain through targeted delivery of a stimulus, e.g., electrical pulses. In this way, errant neural activity may be normalized. Neuromodulation may be applied directly to the location of a neurological problem (e.g., a seizure focus in epilepsy [6]), or to a node or edge in the brain circuit, in which modulation of the target produces an intended net output from the circuit as a whole, such as the subthalamic nucleus (STN) in Parkinson's disease [7]. Non-invasive neuromodulation methods include repetitive transcranial magnetic stimulation (rTMS) and transcranial direct current stimulation (tDCS). Both may be effective in certain clinical conditions, such as rTMS in depression, and have low side effect profiles. However, they are relatively non-focal and thus reserved for large swaths of the superficial cortex on the brain. They lack anatomical specificity, particularly at depth, even when targeted using computerized stereotactic image guidance [8]. Furthermore, rTMS, in particular, is not practical for continuous stimulation throughout the day, every day. The ability to treat clinical conditions by modulating specifically targeted brain circuits remains limited. Surgically implanted electrical stimulation of the brain, such as deep brain stimulation (DBS) and cortical stimulation, are approved for use in most of the world for the treatment of Parkinson's disease, essential tremor dystonia, obsessivecompulsive disorder, and epilepsy. Implanted stimulation is also promising in investigational use for chronic pain, depression, and addiction [9-11]. While potent and anatomically specific, this approach requires invasive neurosurgical procedures, which are accompanied by the inherent risk of surgery within the brain, including bleeding and infection. Further, implanted stimulators are expensive and typically require 
periodic hardware replacement procedures throughout the patient's life.

\section{From radiosurgery to radiomodulation}

The virtues of these sundry neuromodulation methods range from high anatomic precision and potency to less invasive, less potent, and less anatomically specific. It would seem reasonable that the optimal neuromodulation is non-invasive and both highly focal and durable in its effect. With this objective, the authors examine the utility of non-ablative, small-field ionizing radiation delivered to brain tissue. This class of procedure is termed "radiomodulation" by a small number of researchers currently exploring the field.

Stereotactic radiosurgery has been used for decades for functional neurosurgery [12,13], including thalamotomy for chronic pain [14-16], pallidotomy for movement disorders [17], and ventral anterior capsulotomy for obsessive-compulsive disorder [18,19]. However, these procedures were intended to truncate or ablate neural connections by inducing cell death [12,13,18]. By contrast, the sine qua non of radiomodulation is the alteration in function of living, viable neurons and glia.

\section{Radiation-induced effects}

Almost a century of research on the biological effects of ionizing radiation on tissue has revealed five factors that are critical in determining the net effect [20,21]: (1) repair of sublethal cellular damage, (2) repopulation of cells following radiation, (3) redistribution of cells within the cell cycle, (4) reoxygenation of the surviving cells, and (5) the radiosensitivity of the tissue and cells within. Accordingly, the post-radiation period involves a complex set of changes to neurons, glia, immune cell populations, and vascular and perivascular cells.

Immediate and early radiation effects occur from the first few minutes to the first few days following exposure. Irradiated tissue absorbs energy, causing changes in enzyme activity, primarily deactivation involving nicotinamide adenine dinucleotidase, adenosine triphosphatases, acid and alkaline phosphatases, cathepsin-type $\mathrm{C}$ esterases, glutamate dehydrogenases and synthases, and succinate dehydrogenases. Some enzymes increase in activity due to metabolic reactions. Enzymes are destroyed via free radicals produced through changes in structure by splitting off amino acids and through denaturation. There is an increase in activity of other enzymes, an accumulation of substrates of these enzymes (primarily glycogen and glycoproteins), and changes in the distribution of electrolytes. Perhaps, most famously, there is radiation damage to the karyoplasm, with damage and loss of DNA. In neurons, there is acute edema and tigrolysis within 30 minutes as ribosomes are lost [21]. In the vasculature, arteries spasm and capillaries show endothelial cell changes within minutes of exposure, with lysosomes increasing and pinocytic vesicles multiplying. Endothelial cells are desquamated, thrombi appear, and interstitial spaces surrounding the capillaries disappear. As a consequence, there is retardation of blood flow. Among glia, astrocytes manifest the first signs of irradiation, with hypertrophic cytoplasm and feet, as well as nuclei with dilated pores. Microglia show dystrophy with pyknotic nuclei and swelling of cell bodies. Unlike astrocytes, oligodendrocytes do not show observable early changes [21].

Radiation-induced edema is frequently evident in clinical experience. Because magnetic resonance (MR) imaging principally reflects a shift in hydrogen resonance, it is sensitive to changes in water in the white matter. As a result, asymptomatic MR hyperintensity on T2-weighted MR imaging following radiation usually represents edema. In most cases, the edema completely resolves over time and does not equate with necrosis [22]. Post-radiation white matter changes may result from an increase in extracellular fluid rather than the locally delivered dose as inflammation has been shown to assume a neuroanatomic distribution and not a radiation dose-related distribution pattern [4].

Late radiation-induced changes may be seen after months and may continue progressively for more than a year [23]. Necrosis usually occurs one to two years after radiation, but latency as short as three months and as long as 30 years has been reported [24,25]. Vascular degeneration is manifested by telangiectasis, capillary proliferation, wall thickening, perivascular edema, thrombosis, and petechial hemorrhages. Conversely, capillaries and small venules may widen. Glial atrophy, which first appears in short-term effects, may continue for years. Leukoencephalopathy is white matter injury, with histopathology showing thinning of white matter, loss of oligodendrocytes, reactive astrogliosis, and areas of necrosis [27]. Generalized atrophy of nervous tissue probably caused by glial cell depletion without clear signs of vascular injury or necrosis can occur even at low doses and after long follow-up times [23].

These features of focal radiation-induced changes, both short-term and late-term, are exploited in the clinical setting today, mainly to control cancer cell growth or to promote the destruction of vascular formations. However, there is both animal and human research that radiation may also modulate neuronal transmission in unique pathways.

\section{Animal studies that suggest a radiomodulation effect}

Key pre-clinical studies that suggest a radiomodulation effect are summarized in Table 1 . They show 
evidence of inhibition of sodium channels, reduced synaptic transmission, hyperpolarization of neurons, necrosis at high target volumes, reduced epileptiform spiking, reduced pre-synaptic and post-synaptic responses, reduction of inhibition, and shortened action potentials.

\begin{tabular}{|c|c|}
\hline Reference & Paradigm \\
\hline $\begin{array}{l}\text { Mullin et } \\
\text { al. [27] }\end{array}$ & $\begin{array}{l}1-100 \text { Gy to the whole brain of a live rat. } \\
\text { Observations ex-vivo immediately post- } \\
\text { radiation }\end{array}$ \\
\hline $\begin{array}{l}\text { Tolliver et } \\
\text { al. [28] }\end{array}$ & $\begin{array}{l}\text { Guinea pig at various dose rates. } \\
\text { Observations ex-vivo in hippocampal } \\
\text { slice immediately post-radiation }\end{array}$ \\
\hline $\begin{array}{l}\text { Pellmar et } \\
\text { al. [29] }\end{array}$ & $\begin{array}{l}\text { Guinea pig hippocampus: } 5-65 \text { Gy to the } \\
\text { whole brain of a live animal. } \\
\text { Observations in slice immediately post- } \\
\text { radiation }\end{array}$ \\
\hline $\begin{array}{l}\text { Yamaguchi } \\
\text { et al. [30] }\end{array}$ & $\begin{array}{l}\text { Dog: } 15 \text { Gy to the whole brain. } \\
\text { Observations } 3-30 \text { months post- } \\
\text { radiation }\end{array}$ \\
\hline $\begin{array}{l}\text { Chen et al. } \\
\text { [31] }\end{array}$ & $\begin{array}{l}\text { Rat epilepsy model: } 20 \text { Gy and } 40 \text { Gy } \\
\text { gamma knife with } 4 \mathrm{~mm} \text { collimator }\end{array}$ \\
\hline $\begin{array}{l}\text { Brisman et } \\
\text { al. [32] }\end{array}$ & $\begin{array}{l}\text { Rat hippocampus: } 90 \text { Gy proton beam to } \\
\text { rat brain, observations } 3 \text { months post- } \\
\text { radiation }\end{array}$ \\
\hline $\begin{array}{l}\text { Dagne et } \\
\text { al. [33] }\end{array}$ & $\begin{array}{l}\text { Rat: whole-brain radiation at } 60 \mathrm{~Gy} \text {, } \\
\text { observations at } 1 \text { day and } 1 \text { week post- } \\
\text { radiation }\end{array}$ \\
\hline $\begin{array}{l}\text { Yeh et al. } \\
{[34]}\end{array}$ & $\begin{array}{l}\text { Pigs: } 10-120 \text { Gy } 7.5 \mathrm{~mm} \text { diameter targets } \\
\text { in M1 and internal capsule. PET and } \\
\text { MRI: baseline to } 9 \text { months post-radiation }\end{array}$ \\
\hline $\begin{array}{l}\text { Gilly et al. } \\
\text { [35] }\end{array}$ & $\begin{array}{l}\text { Squid: } 140-300 \text { Gy to } 9 \mathrm{~mm} \text { diameter } \\
\text { target on stellate ganglion } 24 \text { hours } \\
\text { post-radiation }\end{array}$ \\
\hline
\end{tabular}

\section{Effect observed}

Radiation causes an inhibitory effect on voltage-sensitive sodium channels

Reduced synaptic transmission efficiency

Radiation causes chronic hyperpolarization of neurons and reduced ability of synaptic potential to generate a spike; however, synaptic efficiency increases

Small cell infiltration after 6 months. Necrosis at 9-15 months, with vascular narrowing. More cells in the reproductive phase post-radiation. DNA transcription at a maximum after 9 months and a minimum after 3 months

Synaptically driven firing unchanged. Epileptiform spiking decreased by $55 \%$, with effect sustained for months. Reduced seizure frequency. Cell death in $7 \%$ of the targeted tissue

Higher voltages required to elicit post-synaptic potentials. Reduced response pre-synaptically and post-synaptically.

60 Gy produced a reduction of $\mathrm{GABA}_{A}$ slow inhibition

Doses 60 Gy and above reduces FDG-PET signal at M1 target. Doses 10-40 Gy increases PET signal

Action potential recorded from the giant motor axon in response to electrical stimulation showed an increased maximum rate of fall and a shortened action potential duration

\section{TABLE 1: A summary of animal studies suggesting a radiomodulation effect.}

DNA: deoxyribonucleic acid; FDG-PET: 18 F-fluorodeoxyglucose-positron emission tomography; GABA $\mathrm{A}$ : gamma-aminobutyric acid type A; MRI: magnetic resonance imaging; PET: positron emission tomography

Any of these effects observed could plausibly result in up-regulation or down-regulation of the targeted brain region. For example, the inhibition of sodium channels in an inhibitory brain circuit node would plausibly result in net up-regulation of the output of that node.

Animal studies have also suggested a novel bimodal effect of radiation on motor cortex activity, depending upon the dose. Yeh et al. utilized 18 F-fluorodeoxyglucose-positron emission tomography (FDG-PET) imaging to identify areas of increased or decrease brain metabolism following stereotatic radiosurgery in a healthy Lee Sung miniature pig model [34]. Following the identification of the left primary motor cortex (M1) nine pigs were treated using isocentric target doses of either $0,10,20,30,40,60,80,100$, or $120 \mathrm{~Gy}\left(\mathrm{D}_{\max }\right)$ to the left (unilateral) $10 \mathrm{~Gy}$ to $120 \mathrm{~Gy}$ ( $\mathrm{D}_{\max }$ ) using a $7.5 \mathrm{~mm}$ collimator. The animals were followed for nine months with MR imaging sequences to assess for structural changes and with FDG-PET as an indicator of metabolic activity, both every three months. In a demonstration of bimodal effects of focally delivered radiation on neural metabolic activity, it was shown that the ratio of PET standardized uptake value at the targeted M1 relative to the non-targeted contralateral side was significantly lowered from baseline at a dose of $60 \mathrm{~Gy}$ or greater at nine months post-radiation. By contrast, doses of 10 to $40 \mathrm{~Gy}$ (but not $0 \mathrm{~Gy}$ ) yielded increased PET signal relative to the contralateral. A lesion using T2-weighted MR imaging was visible only in the animal treated with $120 \mathrm{~Gy}$ at nine months post-radiation (Figure 1) [34]. No changes in motor function were observed. While exploratory, further study of these animals with histological analysis will provide 


\section{Cureus}

insight into dose tolerance thresholds with respect to structural tissue changes (pending publication, personal communication).

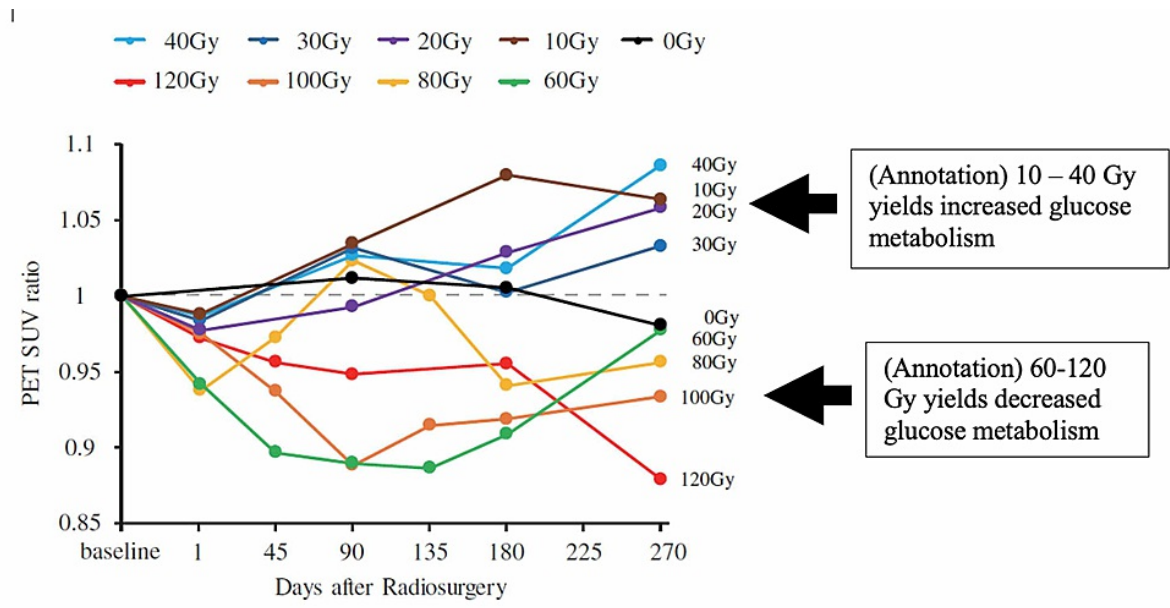

FIGURE 1: Yeh et al. showed 10-40 Gy increases and 60-120 Gy decreases in metabolism by PET in a focal cortical brain region. A 7.5$\mathrm{mm}$ diameter radiosurgical target in the left primary motor cortex. FDGPET signal at target relative to the contralateral region followed up to 270 days post-radiation.

FDG-PET: 18 F-fluorodeoxyglucose positron emission tomography; M1: primary motor cortex; PET: positron emission tomography; SUV: standardized uptake value at target zone versus contralateral zone

Reprinted with permission with annotations (Yeh et al. [34])

\section{Clinical studies that suggest a radiomodulation effect}

There are also observations in human patients that suggest radiation-based neuromodulation. For example, a subset of patients being treated for trigeminal neuralgia, for unclear reasons, experience near-immediate pain relief following radiosurgery. By contrast, the known cellular changes expected from this procedure require several months to manifest. This observation suggests that radiosurgery may modulate neuronal transmission in grossly intact neurons. Additional clinical evidence may be seen following radiosurgical treatment of brain arteriovenous malformation (AVM) with associated seizures. Post-procedure, seizure frequency decreases, despite the persistence of residual AVM. It may be that the seizure focus in the neuronal tissue around/within the malformation is affected by the radiation dose received, independent of the intended long-term sclerotic effect on the vascular tissue.

Some key clinical observations that suggest a radiomodulation effect in humans are summarized in Table 2 . 


\section{Cureus}

\begin{tabular}{|c|c|c|}
\hline Reference & Paradigm & Effect observed \\
\hline $\begin{array}{l}\text { Smith et al. [36] } \\
\text { Borchers et al. [37] } \\
\text { Gorgulho et al. [38] }\end{array}$ & SRS for trigeminal neuralgia & Immediate effect of SRS on trigeminal nerve pain \\
\hline $\begin{array}{l}\text { Steiner and } \\
\text { Lindquist [39] } \\
\text { Steiner et al. [40] }\end{array}$ & AVM with seizures & SRS for AVMs reduces seizure frequency \\
\hline Barbaro et al. [41] & $\begin{array}{l}\text { Pharmacoresistant unilateral MTLE at } 24 \text { Gy to the } \\
50 \% \text { isodose }\end{array}$ & SRS reduces seizure frequency \\
\hline Warnke et al. [42] & $\begin{array}{l}\text { Interstitial radiosurgery of seizure-generating } \\
\text { gliomas }\end{array}$ & $\begin{array}{l}\text { Radiation increases density of benzodiazepine } \\
\text { receptors at the target }\end{array}$ \\
\hline
\end{tabular}

\section{TABLE 2: A summary of supporting clinical literature supporting a radiomodulation effect.}

AVM: arteriovenous malformation; MTLE: mesial temporal lobe epilepsy; SRS: stereotactic radiosurgery

There is growing evidence that focal brain activity may be modulated via radiosurgery in the absence of a visible lesion on MR imaging or computed tomography. Radiomodulation studies to date, however, have been designed in narrowly constructed paradigms, and there remains much to be learned. While both the animal and human studies offer clues, they are disparate in their designs and execution. Perhaps most conspicuously, they vary greatly in terms of dose, treatment volume, anatomical target, and intended effect. Limitations in our understanding include knowledge of the lower threshold of the dose required to modulate specific nodes within specific brain circuits and the upper thresholds at which cellular damage and lesion formation occurs. Is the gray matter of the superficial cortex of the same or different radiosensitivity than the cingulate cortex or subcortical nuclei? The long time course required to evaluate for the development of post-radiation changes, particularly at the histological level, also makes investigation challenging and necessary. Other hurdles to adoption include direct comparison to existing approaches, namely, DBS. While focal radiation is not "reversible" like DBS, it does not share the same surgical risks as passing an electrode deep within the brain. With a better understanding of effective doses and targets, focal radiation may prove to be an effective neuromodulation tool.

\section{Conclusions}

Radiomodulation may provide an opportunity for the non-invasive treatment of dysfunctional brain circuits in human disorders. In principle, this would permit the neuromodulation of targeted brain circuits in functional conditions including movement disorders and some psychiatric disorders. Much work remains to be done in order to define necessary parameters and brain targets.

\section{Additional Information \\ Disclosures}

Conflicts of interest: In compliance with the ICMJE uniform disclosure form, all authors declare the following: Payment/services info: All authors have declared that no financial support was received from any organization for the submitted work. Financial relationships: Bret Schneider and John R. Adler, Jr. declare(s) employment and stock/stock options from Zap Surgical Systems, Inc. Bret Schneider and John R. Adler, Jr. are employees, and hold stock in Zap Surgical Systems, Inc. . Other relationships: All authors have declared that there are no other relationships or activities that could appear to have influenced the submitted work.

\section{References}

1. Whiteford HA, Degenhardt L, Rehm J, et al.: Global burden of disease attributable to mental and substance use disorders: findings from the Global Burden of Disease Study 2010. Lancet. 2013, 382:1575-86. 10.1016/S0140-6736(13)61611-6

2. Insel T, Cuthbert B, Garvey M, et al.: Research domain criteria (RDoC): toward a new classification framework for research on mental disorders. Am J Psychiatry. 2010, 167:748-51. 10.1176/appi.ajp.2010.09091379

3. Régis J, Bartolomei F, Hayashi M, Chauvel P: Gamma Knife surgery, a neuromodulation therapy in epilepsy surgery!. Acta Neurochir Suppl. 2002, 84:37-4. 10.1007/978-3-7091-6117-3_4

4. Régis J, Carron R, Park M: Is radiosurgery a neuromodulation therapy?: A 2009 Fabrikant award lecture . J 
Neurooncol. 2010, 98:155-62. 10.1007/s11060-010-0226-5

5. Schneider B, Borchers J, Adler JR: Radiation-based neuromodulation: rationale and new directions. Cureus. 2010, 2:8. 10.7759/cureus.8

6. Geller EB, Skarpaas TL, Gross RE, et al.: Brain-responsive neurostimulation in patients with medically intractable mesial temporal lobe epilepsy. Epilepsia. 2017, 58:994-1004. 10.1111/epi.13740

7. Deuschl G, Schade-Brittinger C, Krack P, et al.: A randomized trial of deep-brain stimulation for Parkinson's disease. N Engl J Med. 2006, 355:896-908. 10.1056/NEJMoa060281

8. Deng ZD, Lisanby SH, Peterchev AV: Electric field depth-focality tradeoff in transcranial magnetic stimulation: simulation comparison of 50 coil designs. Brain Stimul. 2013, 6:1-13. 10.1016/j.brs.2012.02.005

9. Boccard SG, Pereira EA, Aziz TZ: Deep brain stimulation for chronic pain . J Clin Neurosci. 2015, 22:1537-43. 10.1016/j.jocn.2015.04.005

10. Lozano AM, Mayberg HS, Giacobbe P, Hamani C, Craddock RC, Kennedy SH: Subcallosal cingulate gyrus deep brain stimulation for treatment-resistant depression. Biol Psychiatry. 2008, 64:461-7.

10.1016/i.biopsych.2008.05.034

11. Wang TR, Moosa S, Dallapiazza RF, Elias WJ, Lynch WJ: Deep brain stimulation for the treatment of drug addiction. Neurosurg Focus. 2018, 45:11. 10.3171/2018.5.FOCUS18163

12. Leksell L: The stereotaxic method and radiosurgery of the brain . Acta Chir Scand. 1951, 102:316-9.

13. Leksell L: Stereotactic radiosurgery. J Neurol Neurosurg Psychiatry. 1983, 46:797-803. 10.1136/jnnp.46.9.797

14. Leksell L: Cerebral radiosurgery. I. Gammathalanotomy in two cases of intractable pain . Acta Chir Scand. 1968, 134:585-95.

15. Steiner L, Forster D, Leksell L, Meyerson BA, Boëthius J: Gammathalamotomy in intractable pain. Acta Neurochir (Wien). 1980, 52:173-84. 10.1007/BF01402072

16. Urgosik D, Liscak R: Medial Gamma Knife thalamotomy for intractable pain . J Neurosurg. 2018, 129:72-6. 10.3171/2018.7.GKS181583

17. Rand RW, Jacques DB, Melbye RW, Copcutt BG, Fisher MR, Levenick MN: Gamma Knife thalamotomy and pallidotomy in patients with movement disorders: preliminary results. Stereotact Funct Neurosurg. 1993, 61:65-92. 10.1159/000100662

18. Kondziolka D, Flickinger JC, Hudak R: Results following gamma knife radiosurgical anterior capsulotomies for obsessive compulsive disorder. Neurosurgery. 2011, 68:28-32. 10.1227/NEU.0b013e3181fc5c8b

19. Rasmussen SA, Noren G, Greenberg BD, et al.: Gamma ventral capsulotomy in intractable obsessivecompulsive disorder. Biol Psychiatry. 2018, 84:355-64. 10.1016/j.biopsych.2017.11.034

20. Withers HR: The four R's of radiotherapy. Advances in Radiation Biology. Lett JTAH, Adler H (ed): Academic Press, New York, USA; 1975. 5:241-71. 10.1016/B978-0-12-035405-4.50012-8

21. Steel GG, McMillan TJ, Peacock JH: The 5Rs of radiobiology. Int J Radiat Biol. 1989, 56:1045-8. 10.1080/09553008914552491

22. Valk PE, Dillon WP: Radiation injury of the brain. AJNR Am J Neuroradiol. 1991, 12:45-62.

23. van der Kogel AJ: Central nervous system radiation injury in small animal models . Radiation Injury to the Nervous System. Gutin PH, Leibel SA, Sheline GE (ed): Raven Press, New York, USA; 1991. 23:91-111.

24. Oppenheimer JH, Levy ML, Sinha U, et al.: Radionecrosis secondary to interstitial brachytherapy: correlation of magnetic resonance imaging and histopathology. Neurosurgery. 1992, 31:336-43. 10.1227/00006123199208000-00020

25. Hoshi M, Hayashi T, Kagami H, Murase I, Nakatsukasa M: Late bilateral temporal lobe necrosis after conventional radiotherapy. Neurol Med Chir (Tokyo). 2003, 43:213-6. 10.2176/nmc.43.213

26. Monje M, Wen PY: Neurological complications in adults. Cancer Treat Res. 2009, 150:113-32. 10.1007/b109924_8

27. Mullin MJ, Hunt WA, Harris RA: Ionizing radiation alters the properties of sodium channels in rat brain synaptosomes. J Neurochem. 1986, 47:489-95. 10.1111/j.1471-4159.1986.tb04528.x

28. Tolliver JM, Pellmar TC: Ionizing radiation alters neuronal excitability in hippocampal slices of the guinea pig. Radiat Res. 1987, 112:555-63.

29. Pellmar TC, Schauer DA, Zeman GH: Time- and dose-dependent changes in neuronal activity produced by $\mathrm{X}$ radiation in brain slices. Radiat Res. 1990, 122:209-14.

30. Yamaguchi N, Yamashima T, Yamashita J: A histological and flow cytometric study of dog brain endothelial cell injuries in delayed radiation necrosis. J Neurosurg. 1991, 74:625-32. 10.3171/jns.1991.74.4.0625

31. Chen ZF, Kamiryo T, Henson SL, et al.: Anticonvulsant effects of gamma surgery in a model of chronic spontaneous limbic epilepsy in rats. J Neurosurg. 2001, 94:270-80. 10.3171/jns.2001.94.2.0270

32. Brisman JL, Cole AJ, Cosgrove GR, et al.: Radiosurgery of the rat hippocampus: magnetic resonance imaging, neurophysiological, histological, and behavioral studies. Neurosurgery. 2003, 53:951-61. 10.1227/01.neu.0000083629.92550.a5

33. Dagne BA, Sunay MK, Cayla NS, et al.: High dose gamma radiation selectively reduces GABAA-slow Inhibition. Cureus. 2017, 9:1076. 10.7759/cureus.1076

34. Yeh CI, Cheng MF, Xiao F, et al.: Effects of focal radiation on [18F]-fluoro-d-glucose positron emission tomography in the brains of miniature pigs: preliminary findings on local metabolism [Online ahead of print]. Neuromodulation. 2020, 10.1111/ner.13147

35. Gilly WF, Teal P, Graves EE, Lo J, Schneider MB, Zasio R, Adler JR Jr: Effects of focal ionizing radiation of the squid stellate ganglion on synaptic and axonal transmission in the giant-fiber pathway. Cureus. 2021, 13:13110. 10.7759/cureus.13110

36. Smith ZA, De Salles AA, Frighetto L, et al.: Dedicated linear accelerator radiosurgery for the treatment of trigeminal neuralgia. J Neurosurg. 2003, 99:511-6. 10.3171/jns.2003.99.3.0511

37. Borchers JD 3rd, Yang HJ, Sakamoto GT, Howes GA, Gupta G, Chang SD, Adler JR Jr: Cyberknife stereotactic radiosurgical rhizotomy for trigeminal neuralgia: anatomic and morphological considerations. Neurosurgery. 2009, 64:91-5. 10.1227/01.NEU.0000340795.87734.70

38. Gorgulho A, Agazaryan N, Selch M, Santos BFO, De Salles A: Immediate pain relief elicited after radiosurgery for classical and symptomatic trigeminal neuralgia. Cureus. 2019, 11:4777. 10.7759 /cureus.4777 


\section{Cureus}

39. Steiner L, Lindquist CH: Radiosurgery in cerebral arteriovenous malformations. Neurosurgery: State-of-theArt Review. Stereotactic Surgery. Tasker RR (ed): Hanley \& Belfus, Philadelphia, PA, USA; 1987. 329-36.

40. Steiner L, Lindquist C, Adler JR, Torner JC, Alves W, Steiner M: Clinical outcome of radiosurgery for cerebral arteriovenous malformations. J Neurosurg. 1992, 77:1-8. 10.3171/jns.1992.77.1.0001

41. Barbaro NM, Quigg M, Ward MM, et al.: Radiosurgery versus open surgery for mesial temporal lobe epilepsy: the randomized, controlled ROSE trial. Epilepsia. 2018, 59:1198-207. 10.1111/epi.14045

42. Warnke PC, Berlis A, Weyerbrock A, Ostertag CB: Significant reduction of seizure incidence and increase of benzodiazepine receptor density after interstitial radiosurgery in low-grade gliomas. Acta Neurochir Suppl. 1997, 68:90-2. 10.1007/978-3-7091-6513-3_17 